\title{
Determination of Some Important Emissions of Poultry Waste Co-combustion
}

\author{
Huseyin Topal ${ }^{1}$, Ehsan Amirabedin ${ }^{2},{ }^{1,2}$ Gazi University
}

\begin{abstract}
Poultry Wastes (PW) are rich biomass types which can be utilized as renewable energy sources in energy conversion systems. The PW is a mixture of poultry litter and organic materials spread on the poultry houses ground. In this paper, combustion of the poultry waste alone and mixed with coal in a combustor set up are implemented, and emissions are monitored. Experimental results reveal that, co-combustion of $\mathrm{PW}$ in an existing combustor firing coal can be considered as the best environment-friendly remedy to dispose the facility wastes while reducing the combustion emissions of the system.
\end{abstract}

Keywords - biomass, co-combustion, combustion emission, poultry litter, poultry waste

\section{INTRODUCTION}

Poultry waste is recognized as the main source of pollution from poultry farming. In confined areas, the poultry industry generates a huge amount of waste as a by-product [1]. PW mixture consists of the manure resulting from poultry production, bedding litter used for poultry housing (e.g. sawdust or rice husk), waste feed, dead birds, broken eggs and removed feathers. These by-products components (i.e. litter and manure) have a high nutritional value and can be used as an organic fertilizer, therefore they have traditionally been utilized as an amendment by spreading them on the soil [2]; however, over-application can result in enrichment of water soluble nutrients and in eutrophication of water sources [3].

There are four main alternative disposal routes for poultry waste; composting, anaerobic digestion, gasification and combustion.

Composting is the aerobic (i.e. oxygen-requiring) degradation of organic waste by microorganisms under controlled conditions. The composted material is odorless with lower moisture content. However, composted PW presents some disadvantages. The major problem contributing to waste composting is the nutrient runoff, this nitrogen loss results in an undesirable volatilization of ammonia to the atmosphere or nitrate to water bodies, hence obtained materials will have less economic value [2, 4, and 5]. Anaerobic digestion is a natural process by which agricultural and municipal wastes are decomposed and stabilized by bacteria in the absence of oxygen (i.e. anaerobically) producing methane and other inorganic products including carbon dioxide. This method, however also has some disadvantages and is becoming more and more restricted. Anaerobic digestion of PW is a relatively slow process (10-30 days) and requires liquefaction and the use of plenteous water and there is also a seasonal limitation for this application [6 and 7].

Another alternative disposal method is gasification of PW with the potential for producing $\mathrm{H}_{2}$-rich fuel gas or syngas
$\left(\mathrm{H}_{2}+\mathrm{CO}\right)$. Gasification is a process which involves the conversion of the waste in the presence of gasifying agents like $\mathrm{O}_{2}, \mathrm{CO}_{2}$, water or air at below stoichiometric levels [8 and 9]. Tar formation and related operational problems are among the issues that must be solved [10], furthermore, in contrast to combustion, the gasification of PW has been limited to smallscale and laboratory applications [8].

The forth alternative disposal route is combustion with the potential to provide a sustainable and environmentallyfriendly disposal technology for the PW providing for both facility space heating and large-scale power generation [2]. Combustion of PW represents a promising alternative to energy generation and reduction of emissions of the poultry house facilities.

However, according to the previous studies [11,12 and 13], complete combustion of PW alone due to the high moisture and ash contents as well as low heating value of the poultry waste could result in some problems; therefore, co-combustion of PW with coal (or lignite) can be considered as a better alternative remedy [14].

Co-combustion of poultry wastes with coal has the following advantages [1 and 5]:

- minimization of poultry farming wastes

- reduction of fossil fuel consumption

- minimization of the system emissions

- decrease of the anaerobic release of $\mathrm{CH}_{4}, \mathrm{NH}_{3}, \mathrm{H}_{2} \mathrm{~S}$, volatile organic acids due to the reduced storage time.

The purpose of this paper is to present the results obtained from an experimental study on combustion and co-combustion of PW in a special bottom-feed combustion system with respect to the changes of the emissions characteristics including $\mathrm{CO}, \mathrm{CH}_{4}, \mathrm{O}_{2}, \mathrm{SO}_{2}$ and $\mathrm{NO}_{\mathrm{x}}$ under different excess air ratio (n) and different percentages of poultry waste in a PW+coal mixture. Besides this, combustion losses and efficiency are also observed to get a deeper view into the combustion and co-combustion characteristics of different types of poultry waste.

\section{EXPERIMENTAL}

Two tests are conducted; combustion of PW-only and cocombustion of PW with coal. The $\mathrm{PW}+$ coal ratios (based on mass flow rate) tested are $0 / 100,25 / 75,50 / 50$ and 75/25. For example, $25 \% \mathrm{PW}$ in the $25 / 75$ fuel mixture means that the fuel mass provided by the PW portion of the fuel mixture was $25 \%$ of the total mass flow rate of the fuel mixture and the emission and combustion characteristics of the PW+coal mixture are compared with each other and coal-only results. 
TABLE I

CHARACTERISTICS OF POULTRY LITTER WITH SAWDUST AND POULTRY LITTER WITH RICE HUSK

\begin{tabular}{|c|c|c|c|}
\hline & $\begin{array}{l}\text { Poultry litter with sawdust } \\
\text { (PWS) }\end{array}$ & Poultry litter with rice husk (PWR) & $\begin{array}{c}\text { Tunçbilek } \\
\text { coal }\end{array}$ \\
\hline \multicolumn{4}{|c|}{ Proximate analysis (as received \%) } \\
\hline Moisture & 18.16 & 32.57 & 7.50 \\
\hline Volatile matter & 56.17 & 48.39 & 27.50 \\
\hline Ash & 16.64 & 10.85 & 23.70 \\
\hline Fix carbon & 9.04 & 8.20 & 41.30 \\
\hline Total sulphur & 0.60 & 0.00 & - \\
\hline \multicolumn{4}{|c|}{ Ultimate analysis (as dry basis \%) } \\
\hline Carbon & 37.31 & 39.90 & 59.29 \\
\hline Hydrogen & 4.41 & 4.79 & 4.61 \\
\hline Nitrogen & 9.96 & 8.70 & 2.10 \\
\hline Sulphur & 0.73 & - & 1.81 \\
\hline \multicolumn{4}{|l|}{ Thermal analysis $(\mathrm{kcal} / \mathrm{kg})$} \\
\hline Higher heating value (HHV) & 2992 & 2701 & 5553 \\
\hline Lover heating value (LHV) & 2688 & 2343 & 5273 \\
\hline \multicolumn{4}{|c|}{ Temperature Sensitivity Analysis $\left({ }^{\circ} \mathrm{C}\right)$} \\
\hline Deformation temperature & 1258 & 1360 & - \\
\hline Softening temperature & 1417 & $>1500$ & - \\
\hline Hemisphere temperature & $>1500$ & $>1500$ & - \\
\hline Fusion temperature & $>1500$ & $>1500$ & - \\
\hline
\end{tabular}

\section{A. Fuel characteristics}

In this study Tunçbilek coal and two types of PW (chicken manure with sawdust, PWS and chicken manure with rice husk, PWR) are investigated. Both sawdust and rice husk are raw material for poultry litter and manure. PW properties are important in the combustion processes, particularly moisture content, fractions of fixed volatiles and calorific value.

Proximate, ultimate and temperature sensitivity analyses and calorific values corresponding to both PW types and Tunçbilek coal are presented in Table I. As it is seen from this table, high levels of moisture and ash are recorded for both PW types, which results in heating values approximately $50 \%$ less than that of the coal. Regarding the proximate analysis, coal has a higher carbon and sulphur content than poultry wastes, but on the contrary nitrogen content is higher in waste samples. The hydrogen content is almost equal for all investigated samples.

TABLE II

ANALYSES OF THE ASH OF POULTRY LITTER WITH SAWDUST

\begin{tabular}{cc}
\hline Element & Poultry litter with sawdust \\
\hline $\mathrm{K}_{2} \mathrm{O}$ & 10.86 \\
$\mathrm{Na}_{2} \mathrm{O}$ & 1.68 \\
$\mathrm{MgO}$ & 3.28 \\
$\mathrm{Al}_{2} \mathrm{O}_{3}$ & 2.28 \\
$\mathrm{P}_{2} \mathrm{O}_{5}$ & 10.19 \\
$\mathrm{~S}$ & 6.0 \\
$\mathrm{CaO}$ & 15.82 \\
$\mathrm{Fe}_{2} \mathrm{O}_{3}$ & 7.42 \\
\hline
\end{tabular}

Due to the high mineral content, the ash composition of poultry litter with sawdust is also analyzed and the results are presented in Table II.

\section{B. Experimental set-up}

The experimental set-up is a special bottom-feed combustion system. Via this feeding system, a combustion of high-volatile content coal and biomass with high efficiency and low emissions can be achieved. A schematic diagram of the combustor is shown in Fig. 1. The thermal capacity of the combustor is about $80 \mathrm{~kW}$ and it is used in hot water production. Generally, the experimental set up is designed to operate with chicken farm waste and coal.

The analysis of the flue gas is carried out on the exiting gas from the combustor. Concentrations of $\mathrm{CO}, \mathrm{CH}_{4}, \mathrm{NO}_{\mathrm{x}}$ and $\mathrm{SO}_{2}$ are measured with methods explained in Table III.

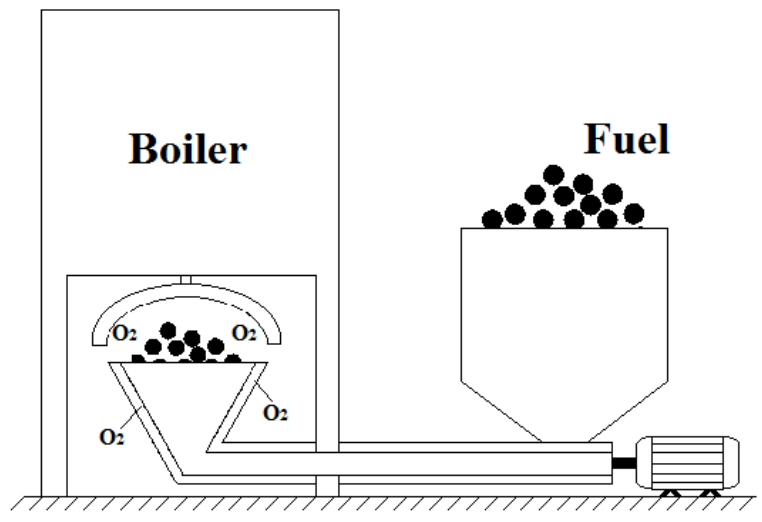

Fig.1. Schematic diagram of combustor

\section{RESULTS}

Combustion and co-combustion experiments are carried out to investigate the feasibility of the poultry waste combustion and to increase the understanding of the dynamic characteristics of the combustion process in the special bottom-feed combustor when using poultry waste and coal+poultry waste mixtures. To this end, the first combustion results including combustion efficiency and $\mathrm{CO}, \mathrm{CH}_{4}, \mathrm{NO}_{\mathrm{x}}$ and $\mathrm{SO}_{2}$ emissions are examined with respect to the excess air ratio variation and then co-combustion tests are carried out in order to investigate the co-combustion performance of poultry waste with rice husk and Tunçbilek coal. 
TABLE III

CHARACTERISTICS OF POULTRY LITTER WITH SAWDUST AND POULTRY LITTER WITH RICE HUSK

\begin{tabular}{|c|c|c|c|}
\hline Analyzer & Methods of measurements & Sensitivity & Meas. ranges \\
\hline $\mathrm{O}_{2} /$ Rosemount & Paramagnetic properties of $\mathrm{O}_{2}$ & $+/-1 \%$ & $0-100(\%)$ \\
\hline $\mathrm{CO}-\mathrm{CO}_{2} /$ Rosemount & NDIR - Non dispersive infrared & $+/-1 \%$ & $500 \mathrm{ppm} / 5 \%$ \\
\hline $\mathrm{CO}-\mathrm{CO}_{2} /$ Rosemount & NDIR - Non dispersive infrared & $+/-1 \%$ & $5 \% / 15 \%$ \\
\hline $\mathrm{SO}_{2} /$ Rosemount & NDUV - Non dispersive ultraviolet & $+/-2 \mathrm{ppm}$ & $2000 \mathrm{ppm}$ \\
\hline $\mathrm{NO}-\mathrm{NO}_{2}-\mathrm{NO}_{\mathrm{x}} / \mathrm{UPK}$ & Chimiluminescence & $+/-1 \mathrm{ppm}$ & $5000 \mathrm{ppm}$ \\
\hline $\mathrm{C}_{\mathrm{m}} \mathrm{H}_{\mathrm{n}} / \mathrm{UPK}$ & $\begin{array}{l}\text { FID-Flame ionization detector (gives hydrocarbon } \\
\text { concentration as } \mathrm{CH}_{4} \text { ) }\end{array}$ & $+/-0.01 \mathrm{ppm}$ & $10000 \mathrm{ppm}$ \\
\hline
\end{tabular}

\section{A. Combustion results}

Fig 2 shows the effect of excess air ratio on the combustion emissions of PWS. Since the sulphur content of the PWS is almost zero, the $\mathrm{SO}_{2}$ emission could be ignored, therefore the pollutants emission focuses on the $\mathrm{NO}_{\mathrm{x}}, \mathrm{CO}$ and $\mathrm{CH}_{4}$ concentrations in flue gas. As it can be seen from this figure, the increase of excess air ratio from 1.30 to 2.73 has a very little effect on $\mathrm{NO}_{\mathrm{x}}$ emission, but it first leads to a sharp decrease and then a notable increase in the $\mathrm{CO}$ and $\mathrm{CH}_{4}$ emissions. The reason for the $\mathrm{CH}_{4}$ increase after 1.55 excess air ratio is probably the presence of the un-oxidized hydrocarbons $\left(\mathrm{C}_{\mathrm{m}} \mathrm{H}_{\mathrm{n}}\right)$ due to the insufficient residence time of the volatile matters in the combustor as a result of the high excess air ratio [15].

In conclusion, this observation indicates that, for minimizing the emissions of the PWS combustion, the ideal excess air ratio is in the range of 1.5-1.6.

Fig 3. displays the variations in $\mathrm{CO}, \mathrm{CH}_{4}, \mathrm{NO}_{\mathrm{x}}$ and $\mathrm{SO}_{2}$ emissions by increase of excess air ratio from 1.29 to 2.23 for PWR combustion. Similar to the combustion of PWS, the increase of the excess air ratio has an insignificant effect on $\mathrm{NO}_{\mathrm{x}}$ and $\mathrm{SO}_{2}$ emissions, but it plays a major role on $\mathrm{CO}$ and $\mathrm{CH}_{4}$ emissions changes. It must be noted that the oxygen concentration can restrain the $\mathrm{CO}$ formation [1].

However, an excess air ratio range of 1.45-1.50 can be considered as optimum value from the $\mathrm{CO}$ and $\mathrm{CH} 4$ concentration point of view.

Considering the fact that the system is working under the ideal condition (i.e. most proper range of the excess air ratio), the minimum emissions for both cases (PWS and PWR) are obtained and summarized in Table IV. On the other hand, emission limits for different types of fuel according to the Air Quality Control Regulation (AQCR) of Turkey are presented in Table V. Comparing data in two tables reveals that only the $\mathrm{CO}$ concentration is found to exceed the limit value.

The effect of excess air ratio on the $\mathrm{L}_{\mathrm{CO}}$ (combustion loss due to carbon monoxide incomplete combustion), $\mathrm{L}_{\mathrm{Ch}}$ (combustion loss due to hydrocarbons incomplete combustion), $\mathrm{L}_{\mathrm{C}}$ (combustion loss due to unburned carbon in ash) and combustion efficiency of the PWS combustion are shown in fig $4 . \mathrm{L}_{\mathrm{CO}}$ and $\mathrm{L}_{\mathrm{Ch}}$ can be calculated using $\mathrm{CO}$ and $\mathrm{C}_{\mathrm{m}} \mathrm{H}_{\mathrm{n}}$ emissions of the flue gas and $\mathrm{L}_{\mathrm{C}}$ calculation is made by weighing and analyzing the collected ash from the ash hopper at the bottom of the combustor.

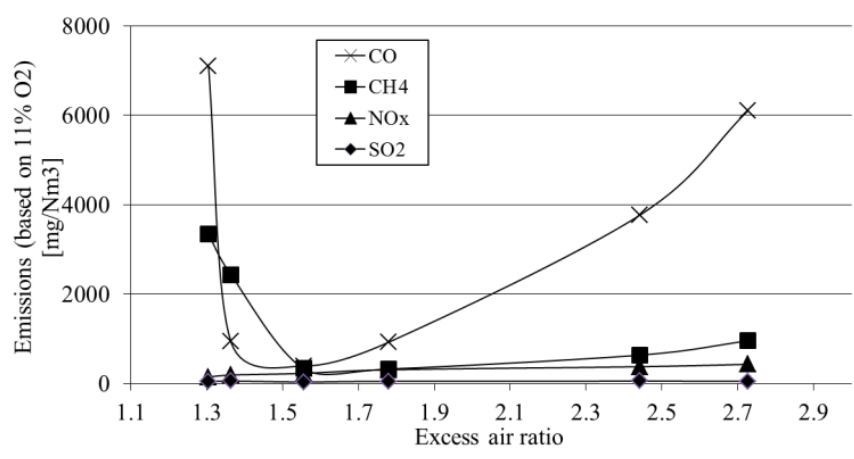

Fig.2. $\mathrm{CO}, \mathrm{CH}_{4}, \mathrm{NO}_{\mathrm{x}}$ and $\mathrm{SO}_{2}$ emissions of combustion of the poultry litter with sawdust (PWS).

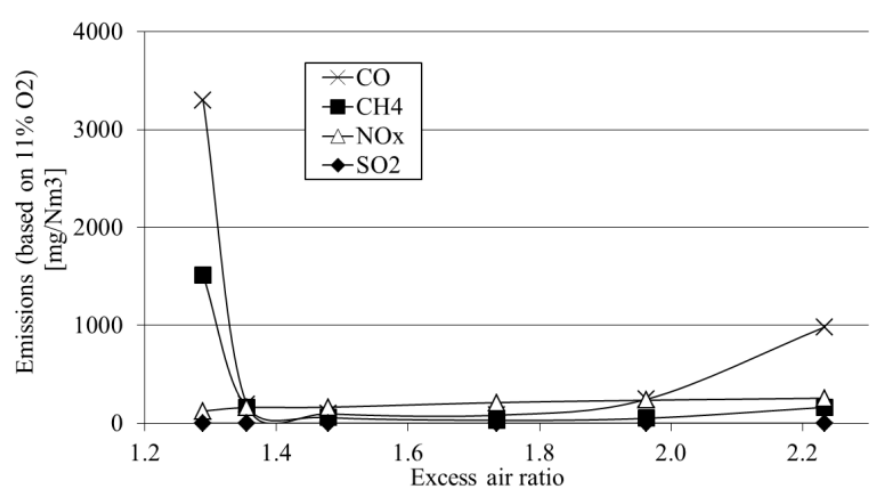

Fig.3. $\mathrm{CO}, \mathrm{CH}_{4}, \mathrm{NO}_{\mathrm{x}}$ and $\mathrm{SO}_{2}$ emissions of combustion of the poultry litter with rice husk (PWR).

All losses show a significant reduction by increasing the excess air ratio from 1.3 to 1.6 , particularly the hydrocarbons loss by $18 \%$, but the further increase of the excess air ratio from 1.6 to 2.7 results in a steady increase. At the same time, combustion efficiency first increases to almost $94 \%$ and when excess air ratio reaches over 1.7, a notable drop is observed. The reason may be the higher elutriation rate of the excess air. Therefore, an excess air ratio range of 1.6-1.7 can be chosen as the most appropriate operation range for PWS combustion from the combustion efficiency perspective.

The effect of the excess air ratio on combustion performance of the PWR is illustrated in Fig. 4. It is shown that the variations of the unburned carbon losses and 
combustion efficiency follow almost similar trends to those of PWS combustion, but the same result cannot be observed for incomplete hydrocarbon and carbon monoxide combustion. Fig. 5 indicates that, despite the remarkable reduction of $\mathrm{L}_{\mathrm{Ch}}$ and $\mathrm{L}_{\mathrm{CO}}$ for increase of the excess air ratio from 1.3 to 1.4 , these losses remain almost unchanged and near to zero when the excess air ratio reaches over 1.4. The expected reason for this is the higher volatile matter contents of the PWR in comparison to the PWS.

However, from the combustion performance aspect, the excess air ratio of 1.5-1.75 can be considered as the best operation range for PWR combustion.

TABLE IV

STACK GAS EMISSIONS WHILE SYSTEM OPERATES UNDER THE IDEAL CONDITION

\begin{tabular}{llll}
\hline Fuel & $\mathrm{CO}\left[\mathrm{mg} / \mathrm{m}^{3}\right]$ & $\mathrm{SO}_{2}\left[\mathrm{mg} / \mathrm{m}^{3}\right]$ & $\mathrm{NO}_{\mathrm{x}}\left[\mathrm{mg} / \mathrm{m}^{3}\right]$ \\
\hline PWS & 389 & 32 & 224 \\
PWR & 83 & 0 & 212 \\
\hline
\end{tabular}

TABLE V

EMISSION LIMITS FOR FUELS ACCORDING TO AIR QUALITY CONTROL REGULATION (AQCR) OF TURKEY [16]

\begin{tabular}{llll}
\hline Fuel & $\mathrm{CO}\left[\mathrm{mg} / \mathrm{m}^{3}\right]$ & $\mathrm{SO}_{2}\left[\mathrm{mg} / \mathrm{m}^{3}\right]$ & $\mathrm{NO}_{\mathrm{x}}\left[\mathrm{mg} / \mathrm{m}^{3}\right]$ \\
\hline Solid & 250 & 400 & 800 \\
Liquid & 175 & 1700 & 800 \\
Gas & 100 & 100 & 500 \\
\hline
\end{tabular}

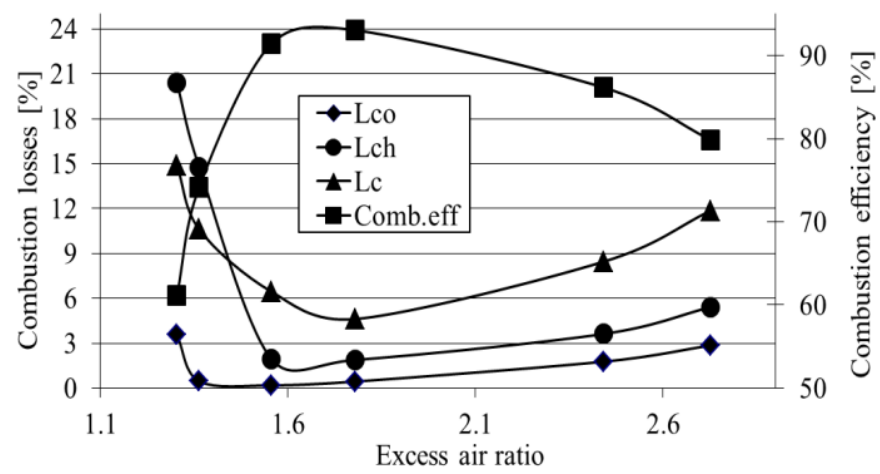

Fig.4. Effect of excess air ratio on the poultry litter with sawdust (PWS) combustion losses $\left(\mathrm{L}_{\mathrm{co}}, \mathrm{L}_{\mathrm{ch}}\right.$ and $\left.\mathrm{L}_{\mathrm{c}}\right)$ and combustion efficiency.

\section{B. Co-combustion results}

In this section, baseline data of co-combustion is first obtained for combustion of the coal alone and then cocombustion tests for poultry waste with rice husk mass fractions of $25 \%, 50 \%$ and $75 \%$ are performed. The combustion emissions of $\mathrm{CO}, \mathrm{CH}_{4}, \mathrm{NO}_{\mathrm{x}}$ and $\mathrm{SO}_{2}$ as a function of PWR mass fraction are shown in Fig. 6. It can be obviously seen that the increase of the PWR mass fraction results in the increase of $\mathrm{CO}$ and $\mathrm{CH}_{4}$ emissions. The cause of the increase of the $\mathrm{CO}$ emission can be categorized as follows [12]:

- Raising hydrocarbon concentration due to the higher amount of volatile matter released from PWR can prevent further CO oxidation [17].
- Relatively high content of PWR results in the formation of $\mathrm{HCl}$, which can inhibit the $\mathrm{CO}$ oxidation by consuming the radicals $\mathrm{OH}$ and $\mathrm{HO}_{2}$ [18].

- Unburned volatile matter can be considered as an additional source of $\mathrm{CO}$ [12].

Furthermore, the increase of $\mathrm{CH}_{4}$ emission by increasing PWR mass fraction can be explained again by higher volatile content of the poultry waste (Table I).

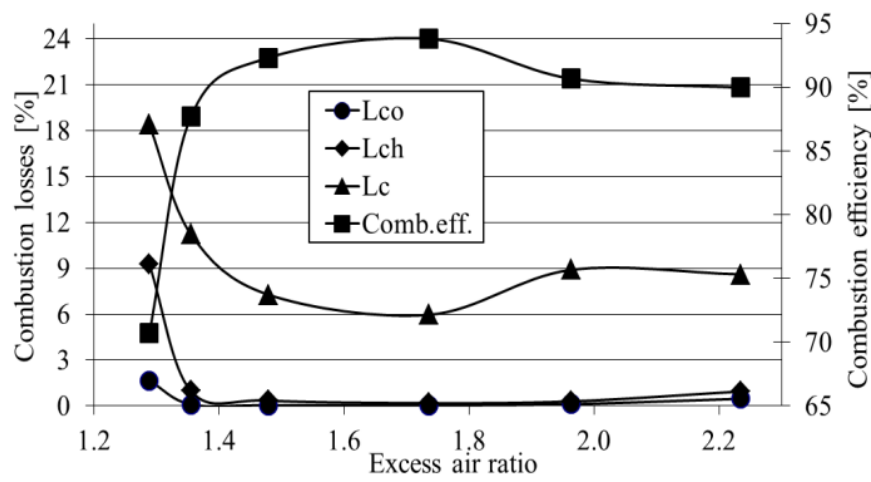

Fig.5. Effect of excess air ratio on the poultry waste with rice husk (PWR) combustion losses $\left(\mathrm{L}_{\mathrm{co}}, \mathrm{L}_{\mathrm{ch}}\right.$ and $\left.\mathrm{L}_{\mathrm{c}}\right)$ and combustion efficiency

Also, as it can be obviously seen from Fig. 6, the increase of PWR mass fraction reduces the $\mathrm{NO}_{\mathrm{x}}$ emission. The probable reason can be explained by the following reaction [19]:

$$
2 \mathrm{NO}+4 \mathrm{NH}_{3}+2 \mathrm{O}_{2} \leftrightarrow 6 \mathrm{H}_{2} \mathrm{O}
$$

Increase of the PWR mass fraction enhances the volatiles and subsequently the fuel-rich condition in the combustor, therefore $\mathrm{NO}_{\mathrm{x}}$ emission decreases via the equation (1) [12].

In addition, Fig. 6 displays that the $\mathrm{SO}_{2}$ emission is decreasing notably as the mass fraction of the coal decreases from $100 \%$ (coal alone) to $25 \%$. The cause for $\mathrm{SO}_{2}$ emission reduction is due to the lower sulphur content of the PWR in comparison to Tunçbilek coal (Table I).

Fig. 7 shows the combustion loss and efficiency variation for different percentage of PWR in the fuel mixture. Combustion losses from incomplete burned carbon monoxide $\left(\mathrm{L}_{\mathrm{co}}\right)$ and incomplete burned hydrocarbons $\left(\mathrm{L}_{\mathrm{Ch}}\right)$ increase and losses from unburned carbon in ash (Lc) decrease while the PWR percentage in the fuel mixture increases. As it explained in the previous section, the higher volatile content of the PWR is responsible for mentioned combustion losses. Moreover, as the PWR percentage increases in the fuel mixture, the combustion efficiency decreases. In summary, the lower coal percentage in the fuel mixture, the lower the combustion losses, so the higher the combustion efficiency. However, it must be noted that the negative effect of PWR addition on the combustion efficiency is almost ignorable (approximately $0.57 \%$ efficiency decrease for $75 / 25$ case). 


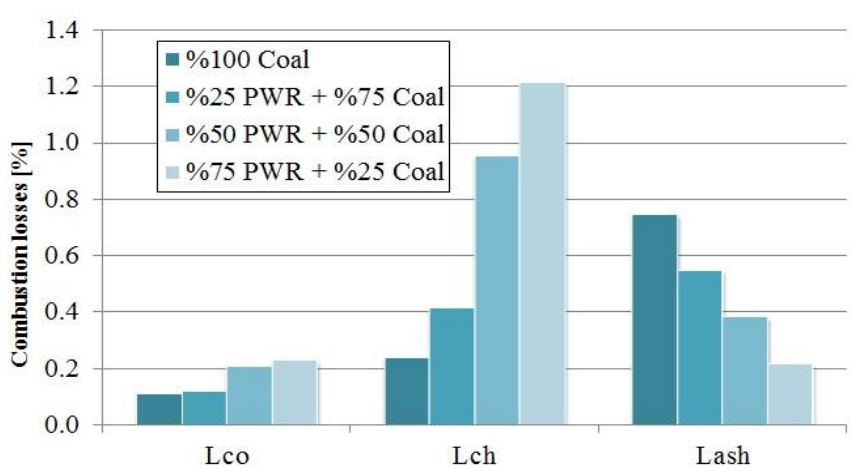

(a)

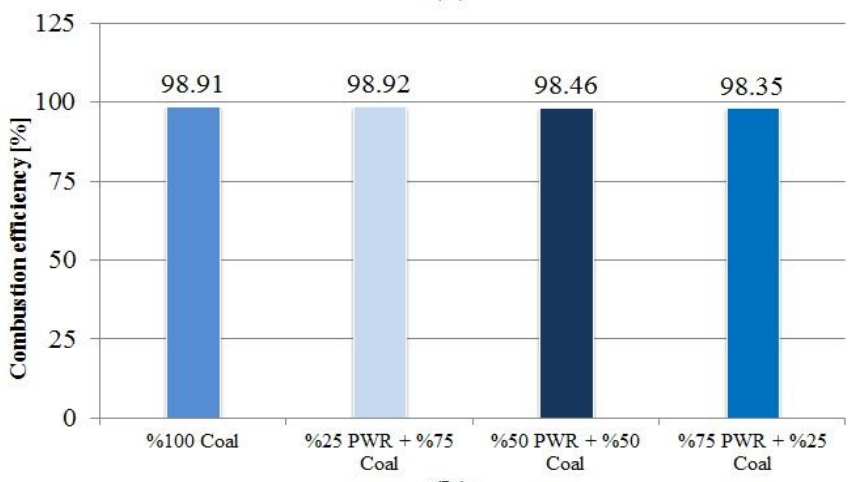

(b)

Fig. 6. $\mathrm{CH}_{4}, \mathrm{NO}_{\mathrm{x}}$ and $\mathrm{SO}_{2}$ emissions of the co-combustion of poultry waste (with rice husk) and Tunçbilek coal

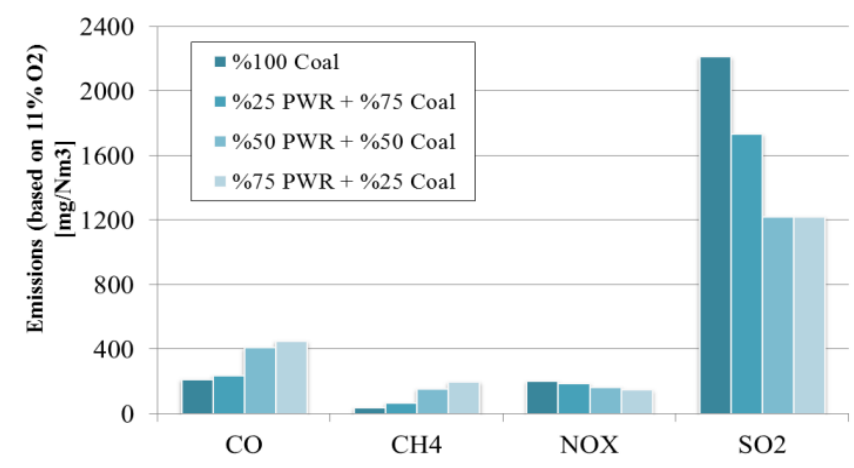

Fig. 7. $\mathrm{CH}_{4}, \mathrm{NO}_{\mathrm{x}}$ and $\mathrm{SO}_{2}$ emissions of the co-combustion of poultry waste (with rice husk) and Tunçbilek coal

\section{CONCLUSION}

The experimental results obtained within this study confirm that combustion of poultry waste can be considered as an alternative source to clean energy generation and efficacious method to reduce the emissions of the poultry house facilities. In this regard two methods are investigated; combustion and co-combustion.

Combustion experimental results reveal that for both PWR and PWS, the increase of the excess air ratio has a remarkable effect on $\mathrm{CO}$ and $\mathrm{CH}_{4}$ emission while its effect on $\mathrm{NO}_{\mathrm{x}}$ and $\mathrm{SO}_{2}$ emissions are ignorable. Moreover, the increase of the excess air ratio leads to first an increase and then a decrease in the combustion efficiency.
Based on the experimental results, for both poultry waste types, an average excess air ratio range of 1.5-1.6 can be considered as optimum value from the combustion performance perspective.

Comparing the combustion results with emissions limit values of the Air Quality Control Regulation (AQCR) of Turkey reveals that, apart from $\mathrm{CO}$ concentration, other emissions are below the allowable limits.

For co-combustion of poultry waste and lignite coal, various ratios of PWR to Tunçbilek coal ranging from 0 to 100 wt. $\%$ are tested. The increase of the PWR mass fraction results in the increase of $\mathrm{CO}$ and $\mathrm{CH}_{4}$ and reduction in $\mathrm{NO}_{\mathrm{x}}$ and $\mathrm{SO}_{2}$ emissions. Combustion efficiency of the PWR co-combustion is found to be about $98-99 \%$.

\section{ACKNOWLEDGEMENT}

The financial support provided to this project by the Gazi University Scientific Research Project (Nr: BAP 06/2005-11) is greatly appreciated.

\section{REFERENCES}

1. Zhu S., Lee S.W. Co-combustion performance of poultry wastes and natural gas in the advanced Swirling Fluidized Bed Combustor (SFBC). Waste Management, 2005, Nr.25, p. 511-518.

2. Kelleher B.P., Leahy J.J., Henihan A.M., O'Dwyer T.F., Sutton D., Leahy M.J. Advances in poultry litter disposal technology - a review, Bioresource Technology, 2002, Nr. 83, p. 27-36

3. Henihan A.M., Leahy M.J., Leahy J.J., Cummins E., Kelleher B.P. Emissions modeling of fluidised bed co-combustion of poultry litter and peat, Bioresource Technology, 2003, Nr. 87, p. 289-294

4. Dávalos Juan Z., Roux M.V., Jiménez P. Evaluation of poultry litter as a feasible fuel, Thermochimica Acta, 2002, Nr. 394, p. 261-266

5. Sweetena J.M, Annamalaib K., Thien B., McDonald L. A. Co-firing of coal and cattle feedlot biomass (FB) fuels. Part I. Feedlot biomass (cattle manure) fuel quality and characteristics, Fuel, 2003, Nr. 83, p. 1167-1182

6. Zhang S., Hong R., Cao J., Takarada T., Influence of manure types and pyrolysis conditions on the oxidation behavior of manure char, Bioresource Technology, 2009, Nr. 100, p. 4278-4283

7. Florin N.H., Maddocks A.R., Wood S., Harris A.T., High-temperature thermal destruction of poultry derived wastes for energy recovery in Australia, Waste Management, 2009, Nr. 29, p. 1399-1408

8. Gasification. Higman, C., van der Burgt, M., Gulf Professional Publishing, 2003, United States of America.

9. Font-Palma C., Characterization, kinetics and modelling of gasification of poultry manure and litter: An overview. Energy Conversion and Management, 2012, Nr. 53, p. 92-98

10. Kelleher B.P., Leahy J.J., Henihan A.M., O'Dwyer T.F., Sutton D., Leahy M.J., Advances in poultry litter disposal technology - a review, Bioresource Technology, 2002, Nr. 83, p. 27-36

11. Abelhaa P., Gulyurtlua I., Boavidaa D., Seabra Barrosa J., Cabritaa I., Leahyb J., Kelleherb B., Leahyc M., Combustion of poultry litter in a fluidized bed combustor. Fuel, 2003, Nr. 82, p.687-692

12. Li S., Wu A., Deng S., Pan W., Effect of co-combustion of chicken litter and coal on emissions in a laboratory-scale fluidized bed combustor, Fuel Processing Technology, 2008, Nr. 89, p. 7-12

13. Otero M., Sánchez M.E., Gómez X., Co-firing of coal and manure biomass: A TG-MS approach, Bioresource Technology, 2011, Nr. 102, p. 8304-8309

14. Jia L., Anthony E.J., Combustion of poultry-derived fuel in a coal-fired pilot-scale circulating fluidized bed combustor, Fuel Processing Technology, 2011, Nr. 92 p. 2138-2144

15. Atimtay A.T., Kaynak B., Co-combustion of peach and apricot stone with coal in a bubbling fluidized bed. Fuel Processing Technology, 2008, Nr. 89 p. $183-197$ 
16. Tarelho L.A.C., Matos M.A.A., Pereira F.J.M.A., Axial and radial CO concentration profiles in an atmospheric bubbling FB combustor. Fuel, 2005, Nr. 84, p. 1128-1135

17. Desroches-Ducarne E., Martya E., Martin G., Delfosse L., Cocombustion of coal and municipal solid waste in a circulating fluidized bed, Fuel, 1998, Nr. 12, p. 1311-1315

18. Lin W.G., Johansen K.D., Proceedings of the Fourth International Conference on Technologies and Combustion for a Clean Environment, Lisbon, Portugal, 1997, p. 9-13.

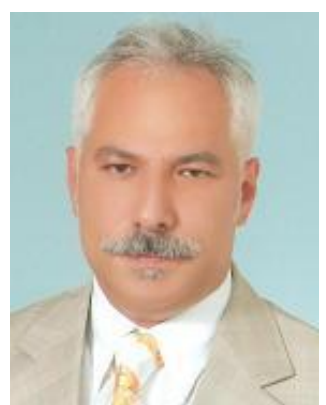

Huseyin Topal completed his first degree studies at Gazi University Engineering and Architecture Faculty at the department of Mechanical Engineering in 1989. He took part in the projects; "Investigation of the Causes of Air Pollution in Ankara and Measures for its Reduction" which are supported from NATO. In addition to these; he also completed his graduate studies within these projects. $\mathrm{He}$ made his $\mathrm{PhD}$ thesis according to the 'Circulating fluidized bed combusters'. Now he also works at Gazi Üniversity Engineering Faculty at the Department of Mechanical Engineering.of Energy Fundamental as a staff member. He continues to work according to 'The Fluidized bed combustion systems, gasification, fuel combustion processing technologies, the risk of environmental, industrial ai pollution control and solid waste management. Currently, he continues his studies at the beginning of biomass, the sources of renewable energies and the environmental effects. Below you can find some of his papers:

Topal H., Atimtay A.T., Durmaz A., Olive Cake Combustion in a Circulating Fluidized Bed, Fuel, Vol 82, 1-8, 2003, Atimtay A.T.,Topal H., Co-combustion of olivecake with lignite coal in a circulating fluidized bed,
Fuel, Vol 83, 7-8, 859-867, 2004, Kaynak B., Topal H., Atimtay A, Peach and apricot stone combustion in a bubbling fluidized bed, Fuel Processing Technology, Vol 86, 1175-1193, 2005.

Address: Gazi University, Faculty of Engineering, Department of Mechanical Engineering, 4th Floor, Room 423, Eti District, Yukselis Street, No:5, PO Box 06570, Maltepe, Ankara, Turkey

Phone: +90 5347394995

E-mail: htopal@gazi.edu.tr

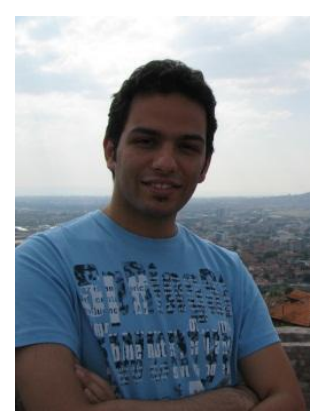

Ehsan Amirabedin was born in Tabriz, Iran, in 1982. He received a B.Sc. degree in mechanical engineering from the Azad University of Tabriz, in 2006, and an M.Sc. degree in mechanical engineering from the Gazi University, Ankara, Turkey, in 2011

$\mathrm{He}$ is currently a PhD student in Gazi University. Six of his papers such as; Amirabedin E., McIlveen-Wright D., A Feasibility Study of Co-Firing Biomass in the Thermal Power Plant at Soma in order to Reduce Emissions: an Exergy Approach, International Journal of Environmental Research, 2012, Amirabedin E., Durmaz A., Second law evaluation and sensitivity analysis of a Thermal Power Plant operating with 10 different types of low grade Turkish lignites, International Journal of Exergy, 2012, 3.

Yilmazoglu M., Amirabedin Ehsan, Second law and sensitivity analysis of a combined cycle power plant in Turkey, Journal of Thermal Science and Technology, 2011, have been published in international academic journals. His current research interests include energy conversion systems, renewable energy systems, combustion \& gasification technologies and energy \& exergy analysis of thermodynamic systems.

E-mail: ehsan.amirabedin@gmail.com 